\title{
Chapter 6 \\ Establishing a New Order: The Orientation of Roman Towns Built in the Age of Augustus
}

\section{A. César González-García}

Instituto de ciencias del Patrimonio, Incipit-CSIC, Avda. de Vigo s/n, 38200, Santiago de

Compostela, Spain

Email: a.cesar.gonzalez-garcia@incipit.csic.es

\section{Andrea Rodríguez-Antón}

Instituto de Astrofísica de Canarias \& Universidad de La Laguna, Vía Láctea s/n, 38200, La

Laguna, Spain

Email: ara_ext@iac.es

\section{David Espinosa-Espinosa}

Universidade de Santiago de Compostela, Departamento de Historia, Faculdade de Xeografía e Historia, Praza da Universidade, 1, 15703, Santiago de Compostela, Spain

Email: david.espinosa@usc.es

\section{Marco V. García Quintela}

Universidade de Santiago de Compostela, Departamento de Historia, Faculdade de Xeografía e

Historia, Praza da Universidade, 1, 15703, Santiago de Compostela, Spain

Email: marco.garcia.quintela@usc.es

\section{Juan A. Belmonte}

Instituto de Astrofísica de Canarias \& Universidad de La Laguna, Vía Láctea s/n, 38200, La

Laguna, Spain

Email: jba@iac.es

\begin{abstract}
Urbanism in most areas of Western Europe occurred at the time of the Roman Empire when several hundred new towns were founded, notably under Augustus. Those towns were planned to incorporate astronomical phenomena as images of propaganda of their rulers, or to connect the city to the gods. The visual effect of the Sun rising in line with the orientation of the city at a given moment in its yearly movement was thus sought and incorporated for its ritual meaning. Special moments allegedly related to Augustus were considered, in particular Winter Solstice and Autumn Equinox.
\end{abstract}

\subsection{Introduction}

Phenomena like the 'Manhattanhenge' have a great visual impact for people today, despite being due to mere chance alignment of an orthogonal grid of streets that happens to face sunset twice a year. However, urban city planning that accommodated celestial movements was not so strange in certain societies, like the Chinese for instance (see Pankenier 2014). Urban grids from classical antiquity, and the Roman realm in particular, may also have incorporated a ritual meaning that connected their layout with the sky.

The foundation of new cities was a key element in Roman expansion, especially in the western part of the Empire (Laurence et al. 2011) where literally hundreds of towns were founded - or re-founded over pre-existing settlements - from the third century BCE to the fourth century CE. Laurence et al. (2011: 138) state that "The grid of streets ... must be analysed as a key aspect of Roman urbanism."

These towns were built in a characteristic shape, incorporating a grid of orthogonal streets with minor variations (Gros 1996; Kaiser 2011). The Roman towns show a high degree of structure and standardization, particularly in the west of the Roman world (Laurence et al. 2011).

The founding of cities in antiquity was not an issue that was left to the mercy of chance, nor was it done in empty spaces devoid of external components. The founding of a town had a deep political and ritual meaning (Woodward and Woodward 2004). In many cases, particularly relating to Roman colonies, it had a clear practical dimension of land control, but also a highly symbolic one, as the new settlement highlighted the role of Rome as the ruler city while the new town was viewed as a small portion of the Urbs itself in the area to be controlled (quasi effigies parvae simulacraque Romae). ${ }^{1}$

\footnotetext{
${ }^{1}$ Gel. XVI, 13, 9 .
} 
In practical terms, the local topography (i.e., rivers, hills, mountains, pathways) affected the location of new settlements and perhaps also their orientation. In other words, cities accommodated and incorporated the surrounding landscape as the Agrimensores and other ancient sources state, such as Hyginio Gromatico (Hyg. Grom., La. 168.3-5). What is generally less taken into account is whether these towns, in one way or another incorporated celestial objects or events as part of that landscape (see e.g. González-García and Magli 2014).

In symbolic terms, numerous sources document how oracles had to be consulted, or rituals had to be elaborated to ascertain the suitability of the time, place or settlers (Rykwert 2002), and a ritual to consecrate the space was a prerequisite, at least until the early centuries of the Roman Empire (Briquel 2008). In many cases such a foundation also involved spatial planning and its delimitation or partitioning.

How Roman cities were orientated as part of these rituals is still a matter of intense debate. The classical sources point to different methods, either purely practical, although based in astronomical observations (such as Vitruvius in de Architectura I, 6) or possibly by a more ritual use of astronomical phenomena, particularly sunrise or sunset, as implied by the accounts of the Agrimensores (e.g. Frontinus De limit., 10.20-11.6 Th; 11.9-14 Th; see Espinosa-Espinosa and González-García 2017 and González-García and Magli 2014 for recent reviews).

The last century of the Republic showed a clear impulse for the building of monumental structures in Rome and in the provinces, that increased during Julian and Augustan times. In fact, a substantial part of the remains visible today in the main area of the forum in Rome date to this period. Likewise, in many towns in the West, massive building plans and embellishment were carried out during the time of Augustus and his successors. For example, an Augustan colony replaced the old town in Brixia (present day Brescia, e.g. L'Année Épigraphique 1996: 726). The series of new colonies founded at the time of Augustus form a homogeneous group with an extremely standard design (González and Ruiz de Arbulo 2010; Owens 1992) and they are the main focus of this paper.

It is a well-known fact that Augustus used astrological images as part of his propaganda agenda, perhaps also reflecting a Hellenistic tradition of using the sky to enhance the ruler cult (see Ferro and Magli 2012 for the connection between the orientation of the city grid in Alexandria and astronomy, and Belmonte and GonzálezGarcía 2010 for the use of astronomy at the Hierothesion of Antiochus of Commagene). This is the case with the appearance of the so-called Caesar's Comet in 44 BCE: Octavianus used such an appearance to highlight his role as sole heir of the Divus Iulius (Ramsey and Licht 1997). Suetonius (Aug XCIV, 12) mentions that Augustus' horoscope was under the sign of Capricorn, something Augustus himself proclaimed and published despite the fact that he was born nearly at the Autumn Equinox, with the Sun in Libra (see e.g. Barton 1995). As part of this propaganda, a large number of coins were struck with a Capricorn sign in its reverse at the time of Augustus and his successors. The Capricorn sign appeared in architectural decorations, in gems (such as the Gemma Augustea) and glass pastes (Galinsky 2012). Capricorn was the constellation housing the Sun during Winter Solstice, the time of solar reborn that Augustus used as an allegory for the re-foundation of Roman customs he was advocating (Barton 1995). Astronomical images and orientations have also been identified in several monuments erected at his time, such as the Pantheon or the Horologium Augusti in Rome (Hannah and Magli 2009; Haselberger 2014; Rehak 2006).

\subsection{Our Hypothesis}

Roman town planning during the Age of Augustus had a strong component of propaganda to impose the image of the ruler as warrant of peace and restorer of the order (Espinosa-Espinosa and González-García 2017). The use of astronomical imagery played a key role in this program.

Thus, our research question is: To what extend did such a program of propaganda extend also to the way Roman settlements in the West were laid out to incorporate orientations towards particular directions, such as Winter Solstice sunrise?

Our working hypothesis then is that the principal public buildings, especially the Forum, or the main axes of the city, faced towards particular points on the horizon where sunrise or sunset at certain times of the year connected to Augustus could be spotted. In particular, the Winter Solstice seems to have been the main target according to our hypothesis. A secondary target would be the equinox when the dies natalis Augusti was supposed to happen.

This hypothesis has already been tested in a small number of Roman towns, with positive results. In recent years there have been two main efforts to understand the issues at stake, either by focusing on particular case studies or by trying to collect samples of data to verify if a common pattern exists.

For Italy and Spain, Magli (2009) and González-García et al. (2014) have shown that a fair number of cities have orientations consistent with sunrise on the Winter Solstice. Although the sample is far from being complete, these works do seem to point towards the actual use of solar observations in the orientation of Roman towns, and the Winter Solstice sunrise seems to have been particularly important.

It is fascinating that a fair number of these towns with astronomical orientations either were founded or reconstructed at the time of Augustus. Three cases of interest where particular astronomical relations appear are Lugdunum (Lyon) in Gaul, Aosta (ancient Augusta Pretoria Salassorum) in Italy and Carthago Nova (Cartagena) in Spain. 
Lugdunum presents an elaborate case where the urban layout fully conforms to Roman models but also matches Gallic traditions (García-Quintela and González-García 2014; González-García and García-Quintela 2014). In particular, the orientation of the town, which is clearly a Roman colony, could be related to a traditional Gallic festival celebrated on 1 August nearly at the foundation period on 43 BC, 31 years before establishing the altar for the Imperial cult, and the festivities to be celebrated on that same day. During that period, the proposed location of the altar of the Tres Galliae, and the orientation of the amphitheater associated with it, allowed viewing of the setting of the constellation of Capricorn over the municipal temple of the Imperial cult built in the heart of the Roman city (Fig. 6.1a). This was a highly evocative game of legitimation of Imperial power that linked the Gaulic festival, performed to honor Rome, and a symbol of that power (Capricorn) associated with the sanctuary of the Imperial cult (González-García and García-Quintela 2014).
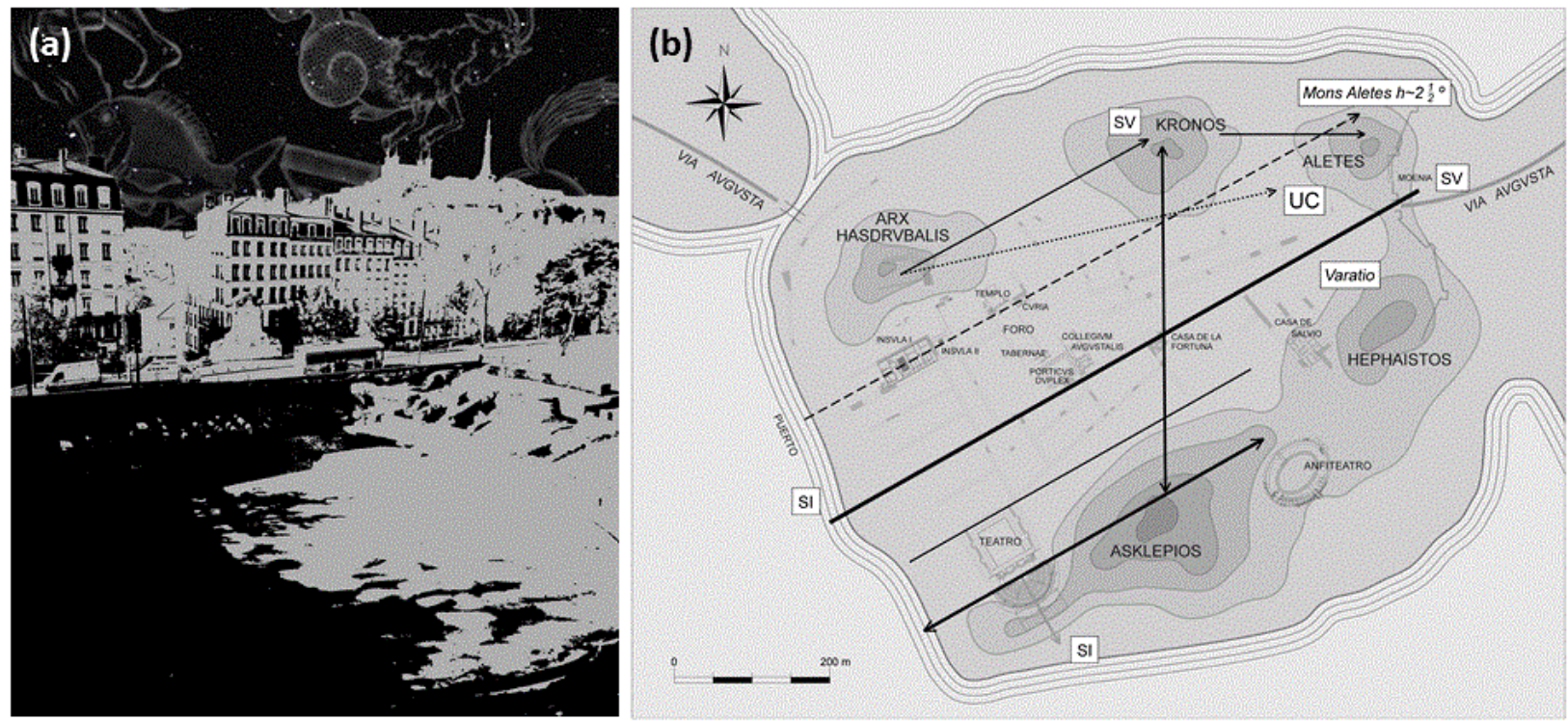

Fig. 6.1 (a) The Roman amphitheater of Lyon was associated with the altar of the Tres Galliae where a yearly meeting of all Gaullic tribes was held on 1 August. On that date, at dawn the constellation of Capricorn could be seen setting behind the municipal temple of the Imperial cult. (b) The urban layout of Carthago Nova surely incorporated the Punic design, but the location of the Forum and its temple to Rome and Augustus was chosen so that summer solstice sunrise happened on top of Mons Aletes, which was arguably devoted to the mythical founder of the town

In Augusta Pretoria we find a similar pattern with orientations towards the Winter Solstice. At Mediterranean latitudes, where the direction of the decumanus generally agrees with the course of the Sun, the perpendicular street, cardo, would be out of this solar arc. However, for Aosta, Bertarione and Magli (2014) have recently revealed that due to its location in a deep valley within the Alps, the south end of the cardo is, also, inside the solar range. That part of the city is facing the top of a nearby mountain, allowing this street to be oriented to the Winter Solstice sunrise, the moment when the Sun was in the constellation of Capricorn.

Carthago Nova (see Belmonte et al. 2016; Gonzalez-Garcia et al. 2015) suffered a re-foundation of the older Carthaginian town with a renewed reading of the local landscape under the Roman and particularly within the Augustan frame of mind. The original Punic layout was reconsidered and, for instance, the area of the forum of the new colony had a slightly modified orientation, such that the temple of the Imperial cult was oriented towards the Summer solstice sunrise on top of a nearby hill devoted to a mythical founder of the site (Mons Aletes according to Polybius $^{2}$; Fig. 6.1b). Augustus or his allies in Carthago Nova linked the new founder with the old one. The landscape of Punic times was modified, reinterpreted and changed along with progressive Romanisation.

It is clear that the two types of studies, survey-like and in-depth, complement each other by providing a detailed picture of the role of astronomy in the orientation and location of cities and public buildings in Roman towns.

\footnotetext{
${ }^{2}$ Pol. 10, 10, 6 .
} 


\subsection{Methodology}

Thus, we have measured the orientation of a number of cities with archaeologically and epigraphically attested Augustan foundations or reforms carried out at that period, in the ancient Roman provinces of Hispania, Gallia, Germania, Italia and North Africa (see Table 6.1).

Table 6.1 Augustan towns measured and considered in the text. All sites were measured in situ, and several structures were measured to obtain a mean azimuth. The columns give the name of the Roman site, its present name, the latitude $(\varphi)$, the azimuth towards east, the altitude of the horizon towards that direction (he), the azimuth towards west, and its altitude of the horizon, and finally the astronomical declination towards east and west. When considering sites at widely different latitudes, the azimuth comparison renders useless, so it is wise to provide a magnitude independent of the observers' location. Such is the declination, an astronomical magnitude that is also directly comparable with the solar positions. For the time of Augustus, the solar range of declinations varied between the nearly $-24^{\circ}$ for the Winter Solstice to the $24^{\circ}$ of the Summer Solstice, while the equinoxes happened for $\delta=0^{\circ}$

\begin{tabular}{|c|c|c|c|c|c|c|c|c|}
\hline Roman Site & Present name & $\varphi$ & $\mathrm{Ae}$ & he & Aw & hw & $\delta \mathrm{e}$ & $\delta \mathrm{w}$ \\
\hline \multicolumn{9}{|c|}{ Germania } \\
\hline Ara Ubi/Colonia & Köln & 50.93 & $901 / 2$ & $01 / 2$ & $2701 / 2$ & 0.5 & 0.07 & 0.25 \\
\hline \multicolumn{9}{|c|}{ Gallia Belgica } \\
\hline Augusta Trev. & \multirow{2}{*}{ Trier } & \multirow{2}{*}{49.75} & 106 & $41 / 2$ & 286 & $51 / 2$ & -7 & 14.25 \\
\hline Petrisberg & & & 131 & $13 / 4$ & 311 & $11 / 4$ & -23.92 & 25.81 \\
\hline Augusta Raurica & Augst & 47.5 & 55 & $13 / 4$ & 235 & $23 / 4$ & 23.93 & -21 \\
\hline Vesontio & Besançon & 47.25 & 135 & 7 & 315 & $11 / 2$ & -22.9 & 29.64 \\
\hline Aventicum & Avenches & 46.86 & 128 & 3 & 308 & 2 & -22.7 & 26.25 \\
\hline \multicolumn{9}{|c|}{ Gallia Lugdunensis } \\
\hline \multirow{2}{*}{ Augustodunum } & \multirow{2}{*}{ Autun } & \multirow{2}{*}{47.00} & $1141 / 2$ & $31 / 4$ & $2951 / 2$ & 1.5 & -14.2 & 17.6 \\
\hline & & & $541 / 2$ & 1 & $2341 / 2$ & $\mathrm{~b}$ & 23.80 & -23.79 \\
\hline Lugdunum & Lyon & 45.75 & 63 & $01 / 2$ & 243 & $\mathrm{~b}$ & 18.48 & -18.9 \\
\hline F. Segusiavorum & Feurs & 45.7 & 80 & $1 \frac{1 / 2}{2}$ & 260 & $11 / 2$ & 7.8 & -6.1 \\
\hline \multicolumn{9}{|c|}{ Gallia Aquitania } \\
\hline Argentomagus & & 46.6 & $943 / 4$ & 1 & $2743 / 4$ & 1 & -2.83 & 3.74 \\
\hline Augustonemeton & Clermont-Ferrand & 45.75 & $903 / 4$ & 1 & $2703 / 4$ & $41 / 4$ & -0.098 & 3.80 \\
\hline Med. Santonum & Saintes & 45.73 & $973 / 4$ & 1 & $2773 / 4$ & 1 & -4.97 & 5.83 \\
\hline Vesunna & Périgueux & 45.17 & 90 & 3 & 270 & $0^{*}$ & 1.95 & -0.41 \\
\hline L. Convenarum & Saint Bertrand C. & 43.00 & $1181 / 2$ & $41 / 2$ & $2981 / 2$ & 3 & -17.25 & 22.42 \\
\hline \multicolumn{9}{|c|}{ Gallia Narbonensis } \\
\hline Vienn & Vienne & 45.5 & $983 / 4$ & 7 & $2783 / 4$ & 5 & -1.2 & 9.6 \\
\hline Alba Helviorum & Alba-la-Romaine & 44.55 & $911 / 4$ & $51 / 2$ & $2711 / 4$ & 5 & 3 & 4.2 \\
\hline Arausio & Orange & 44.13 & $76^{3} / 4$ & 2 & $2563 / 4$ & 1 & 10.6 & -9 \\
\hline Lugdunum & Laudun & 44.11 & $1193 / 4$ & 1 & $2993 / 4$ & 0 & -20.4 & 20.4 \\
\hline Nemausus & Nimes & 43.80 & $771 / 4$ & $01 / 4$ & $2571 / 4$ & 2 & 9 & -8 \\
\hline Apta Iulia Vulg. & Apt & 43.87 & 95 & $23 / 4 *$ & 275 & $03 / 4^{*}$ & -1.8 & 3.8 \\
\hline Glanum & & 43.77 & $81 \frac{1 / 4}{4}$ & $9 *$ & $261 \frac{1 / 4}{2}$ & 6 & 12.5 & -2.2 \\
\hline Arelate & Arles & 43.67 & 90 & 0 & 270 & 0 & -0.4 & -0.4 \\
\hline F. Iulii & Fréjus & 43.43 & $543 / 4$ & $2 *$ & $2343 / 4$ & $2 *$ & 26.1 & -23.5 \\
\hline Ruscino & Perpignan & 42.70 & $913 / 4$ & 0 & $271 \% / 4$ & $11 / 4$ & -1.68 & 2.25 \\
\hline \multicolumn{9}{|c|}{ Italia } \\
\hline Tridentum & Trento & 46.06 & 82 & $81 / 4$ & 262 & $133 / 4$ & 11.43 & 4.42 \\
\hline Aug. Pretoria & Aosta & 45.74 & 68 & 10 & 248 & 5 & 22.4 & -11.55 \\
\hline Brixia & Brescia & 45.54 & 98 & $53 / 4$ & 278 & 0.1 & -1.45 & 5.27 \\
\hline Verona & Verona & 45.44 & 54 & $21 / 2$ & 234 & $01 / 2$ & 26.09 & -24.43 \\
\hline Aug. Taurinorum & Torino & 45.07 & 115 & 2.3 & 295 & $31 / 2$ & -15.86 & 19.86 \\
\hline A. Bagiennorum & Bene Vagienna & 44.56 & 126 & $1 \frac{1}{2}$ & 306 & $13 / 4$ & -23.87 & 25.81 \\
\hline Grumentum & Grumento & 40.28 & 127 & $31 / 2$ & 307 & $11 / 2$ & -24.91 & 28.17 \\
\hline \multicolumn{9}{|c|}{ Hispania Citerior Tarraconensis } \\
\hline Lucus Aug & Lugo & 43.0 & 71 & $11 / 4 *$ & 251 & $13 / 4^{*}$ & 14.4 & -13.6 \\
\hline Iuliobriga & Retortillo & 42.99 & $1241 / 4$ & $01 / 2$ & $3041 / 4$ & 0 & -23.9 & 23.9 \\
\hline Pisoraca & Herrera & 42.59 & $116^{1} / 2$ & 0 & $2961 / 2$ & $01 / 2^{*}$ & -19.1 & 19.12 \\
\hline Legio & León & 42.6 & $693 / 4$ & $1 *$ & $2493 / 4$ & $01 / 2^{*}$ & 15.0 & -14.8 \\
\hline Asturica Aug & Astorga & 42.46 & $701 / 2$ & $01 / 2 *$ & $2501 / 2$ & 2 & 14.2 & -14.6 \\
\hline Tarraca & Los Bañales & 42.28 & $501 / 4$ & 1 & $2301 / 4$ & $-01 / 4$ & 28.68 & -28.90 \\
\hline Petavonium & & 42.08 & $1201 / 2$ & 0 & $3001 / 2$ & $01 / 2$ & -22.1 & 22.06 \\
\hline Cesaraugusta & Zaragoza & 41.65 & $1241 / 4$ & $0^{*}$ & $3041 / 4$ & $0 *$ & -25.30 & 24.44 \\
\hline Bracara Aug & Braga & 41.5 & $72^{1 / 4}$ & $21 / 4$ & $2521 / 4$ & 0 & 14.8 & -13.6 \\
\hline
\end{tabular}




\begin{tabular}{|c|c|c|c|c|c|c|c|c|}
\hline Roman Site & Present name & $\varphi$ & $\mathrm{Ae}$ & he & $\mathrm{Aw}$ & hw & $\delta \mathrm{e}$ & $\delta \mathrm{w}$ \\
\hline Barcino & Barcelona & 41.38 & $1263 / 4$ & 2 & $3063 / 4$ & 4 & -25.42 & 29.46 \\
\hline Aug Bilbilis & Calatayud & 41.36 & 76 & 3 & 256 & 1 & 12.31 & -10.06 \\
\hline Termes & Tiermes & 41.33 & 78 & $01 / 2$ & 258 & 1 & 9.0 & -8.6 \\
\hline Tarraco & Tarragona & 41.11 & $1191 / 2$ & $-01 / 4^{*}$ & $2991 / 2$ & $13 / 4^{*}$ & -22.4 & 22.56 \\
\hline Ercavica & & 40.4 & $801 / 2$ & 0 & $2601 / 2$ & $01 / 2$ & 7.22 & -7.6 \\
\hline Segobriga & & 39.88 & $753 / 4$ & $71 / 2$ & $2553 / 4$ & $01 / 2$ & 15.7 & -10.9 \\
\hline Valeria & Las Valeras & 39.8 & $1203 / 4$ & $-01 / 4$ & $3001 / 2$ & 1 & -23.3 & 23.21 \\
\hline Saguntum & Sagunto & 39.67 & $831 / 2$ & $5^{*}$ & $2631 / 2$ & 4 & 7.80 & -2.88 \\
\hline Libisosa & Lezuza & 38.95 & $871 / 4$ & $-01 / 2$ & $2671 / 4$ & 0 & 1.38 & -2.5 \\
\hline Lucentum & Alicante & 38.3 & $1251 / 4$ & 0 & $3063 / 4$ & $21 / 2$ & -26.9 & 29.28 \\
\hline Carthago Nova & Cartagena & 37.62 & $611 / 2$ & $2 \frac{1}{2}$ & $241 \frac{1}{2}$ & $0^{*}$ & 23.75 & -22.5 \\
\hline \multicolumn{9}{|c|}{ Hispania Ulterior Betica } \\
\hline Corduba & Córdoba & 37.88 & 59 & $01 / 2$ & 239 & 0 & 23.99 & -24.37 \\
\hline Ituci & Torreparedones & 37.75 & 83 & $-01 / 2$ & 263 & $-01 / 2$ & 4.25 & -7.63 \\
\hline \multicolumn{9}{|c|}{ Lusitania } \\
\hline Aug Emerita & Mérida & 38.9 & $523 / 4$ & 0 & $2323 / 4$ & 1 & 28.1 & -27.9 \\
\hline L.Iulia & Ebora & 38.57 & 58 & 0 & 238 & 0 & 24.5 & -24.9 \\
\hline Pax Iulia & Beja & 38.01 & $1271 / 2$ & $-01 / 4$ & $3071 / 2$ & $-01 / 2$ & -29.3 & 28.00 \\
\hline \multicolumn{9}{|c|}{ Africa Proconsularis } \\
\hline Utica & & 37.05 & 105 & $01 / 4 *$ & 285 & $11 / 4^{*}$ & -12.1 & 12.5 \\
\hline Carthago & & 36.88 & 120 & 0 & 300 & $01 / 4$ & -23.95 & 23.4 \\
\hline Uthina & & 36.61 & $55^{1 / 2}$ & $0.5^{*}$ & $2351 / 2$ & $01 / 2^{*}$ & 27.1 & -27.1 \\
\hline Simitthus & & 36.49 & 46 & 0 & 226 & $2^{1 / 2} 2^{*}$ & 33.6 & -32.6 \\
\hline Thuburbo Majus & & 36.4 & 126 & 2 & 306 & $31 / 4$ & -27.1 & 30.2 \\
\hline Lepcis Magna & & 32.6 & $541 / 2$ & 0 & $2341 / 2$ & 1 & 29 & -29.0 \\
\hline \multicolumn{9}{|c|}{ Mauretania Tingitana } \\
\hline Banasa & & 34.60 & $1281 / 2$ & $0^{*}$ & $308^{1 / 2}$ & $0^{*}$ & -31.2 & 30.4 \\
\hline
\end{tabular}

The methodology employed involves the measurement of those archaeological remains that may give us information about the orientation of the urban planning or in those public buildings erected at the time of Augustus. After determining the direction from which we want to set the orientation, we take the azimuth and the horizon altitude for such directions using tandems, including a precision compass and a clinometer. The error of an individual measure, judging from the scale of the instrument (the Suunto 360PC / 360R and the Silva Surveymaster) is $\pm 1 / 4^{\circ}$ for the azimuth and $\pm 12^{\circ}$ for the height of the horizon. Note that in several instances individual measurements will have larger errors due to, above all, the condition of some of the measured remains. Since the instruments used were magnetic, we had to correct the magnetic declination readings. These values are commonly estimated by comparing readings for conspicuous landmarks that can be later be compared with the real directions to correct also for systematic errors in the measuring devices. Where such readings were not possible the magnetic declinations were estimated for the fieldwork dates from the models available in http://www.ngdc.noaa.gov. The values provided in Table 1 have been corrected for these systematics and are the mean of a number of measurments, in all cases larger than five. The standard deviation of those measurements are normally smaller than the errors provided above.

The data could then be compared with estimates for the celestial objects visible on that section of the horizon. To perform this comparison our measurements were translated into astronomical declination, resulting in an error estimate of around $34^{\circ}$, or less than one day in the case of sunrise/sunset.

On a number of occasions, especially for Roman towns in currently sensitive areas due to geostrategic reasons, we could not perform fieldwork and we opted to use satellite images and digital terrain models (DTM). The digital images were normally obtained through the repository Google Earth (GE) and the DTM were accessed via the web application www.heywhatsthat.com (HWT). The accuracy of such measurements depended a lot on a number of considerations (Rodríguez-Antón et al. 2017) and the error estimates on declinations for such measurements had to be determined individually. In general the error estimate was nearly $\pm 1 \frac{1}{2} 2^{\circ}$ although on occasions it could be larger. These measurements were treated separately in the analysis below, and are indicated with an asterisk in Table 6.1. These data also include the measurements by Magli (2008) in Italy. His database was prepared after measuring the orientation of towns on maps and thus was only based on azimuth data. We have checked each measurement there with GE and we have included the altitude of the horizon computed with HWT.

In the following sections, we treat the data collectively by using histograms to analyse the possibility of finding concentrations of orientations that are not expected according to the null hypothesis that Roman towns were not oriented according to the Sun. In particular, we have used a probability density function with a Gaussian kernel instead of the customary box histogram. This representation allows us to treat each measurement independently with its own error as the width of the Gaussian kernel. Thus, those measurements obtained directly by fieldwork will have a smaller spread and thus are weighted more than those obtained through GE and HWT. 


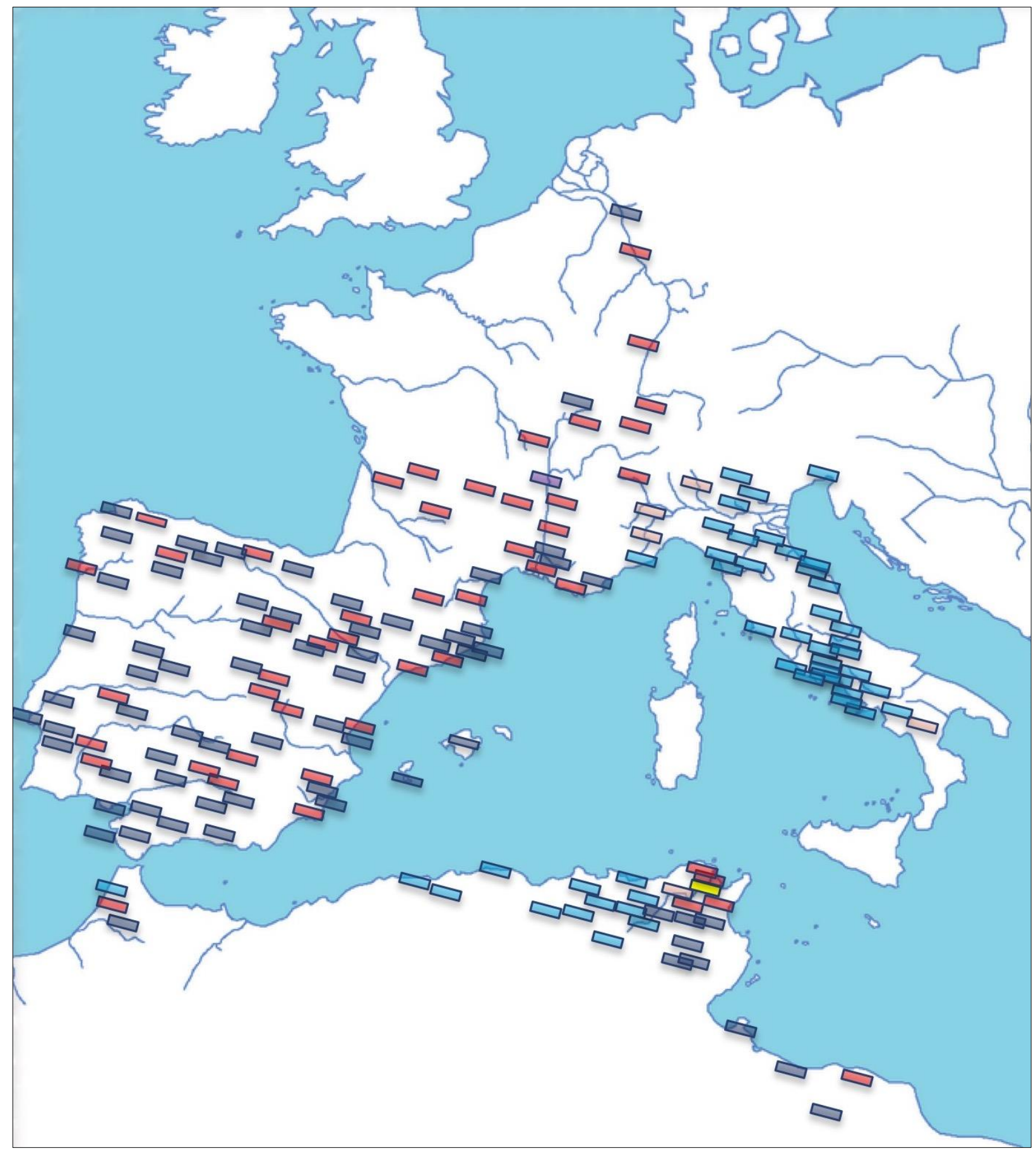

Fig. 6.2 A map of the western part of the Roman Empire showing the data base of the 181 Roman towns that have been measured so far. The red and pink rectangles indicate the 64 Augustan town. Red rectangles are measurments taken on-site by our team, and pink rectangles indicate measurements taken via Digital Terrain Models and orthoimages

\subsection{Results}

Our database of 64 Augustan towns is drawn from the orientations of 181 Roman towns in Hispania, Italy and parts of North Africa, France, Germany, and Switzerland measured mainly by our team during the last decade (see e.g. Rodríguez-Antón 2017; and Fig. 6.2). The database with the 64 Augustan towns is given in Table 6.1. Fig. 6.3a presents the comparison of the full dataset (181 towns), in dark grey, and what we would expect (light grey) if the data were supposed to follow the sunrise on any day of the year homogeneously. From this figure we should expect concentrations close to the solstitial lines (vertical solid lines) and we do find such clustering, but we also find that there are other clusters within these limits that are not expected. However we cannot ascertain whether this is just a 
matter of how the sample was constructed or if these concentrations do actually indicate an intentionality to choose particular dates in the course of the year.

Fig. 6.3b presents the results for the 64 Augustan towns in our sample (dark grey compared with the total sample so far in light grey). It is clear that now the maxima become narrower, sharper and therefore more clearly defined. It must be stressed that these 64 towns are included in the total sample. Fig. 6.3c makes the same comparison with the data not including the Augustan towns. From these two figures we can see that Augustan towns present a more concentrated distribution especially towards Winter Solstice sunrise (declination $-24^{\circ}$ ), equinox (declination $0^{\circ}$ ) and summer solstice sunrise (declination $24^{\circ}$ ). There are other less well-defined concentrations near values of $10^{\circ}-15^{\circ}$.

All these values and comparisons were done for the eastern area of the horizon. Fig. 6.4 compares the orientation of the eastern and western ends of the decumanus. It must be noted that if the eastern end of a given decumanus is oriented towards Winter Solstice sunrise the opposite direction, towards the west will, in general point to summer solstice sunset. However, this is not always the case, as the actual horizon may prevent such symmetry. In the case of Fig. 6.4 if the concond were real we should expect both histograms (light and dark grey) to mirror images of each other, and that the dark grey peak at declination $-24^{\circ}$ should have a light grey counter part at $24^{\circ}$ of similar amplitude. But this is not the case due to the breaking of such symmetry caused by the local horizons at each town. We may observe that the concentrations are generally narrower and sharper for the eastern end, perhaps indicating a better orientation in that directions, and therefore, following the scheme proposed by GonzálezGarcía and Sprajc (2016), an intentionallity towards that direction that fits well with the well-known prevalence of east as main cardinal point in Rome and, in general, in the whole Indo-European tradition.
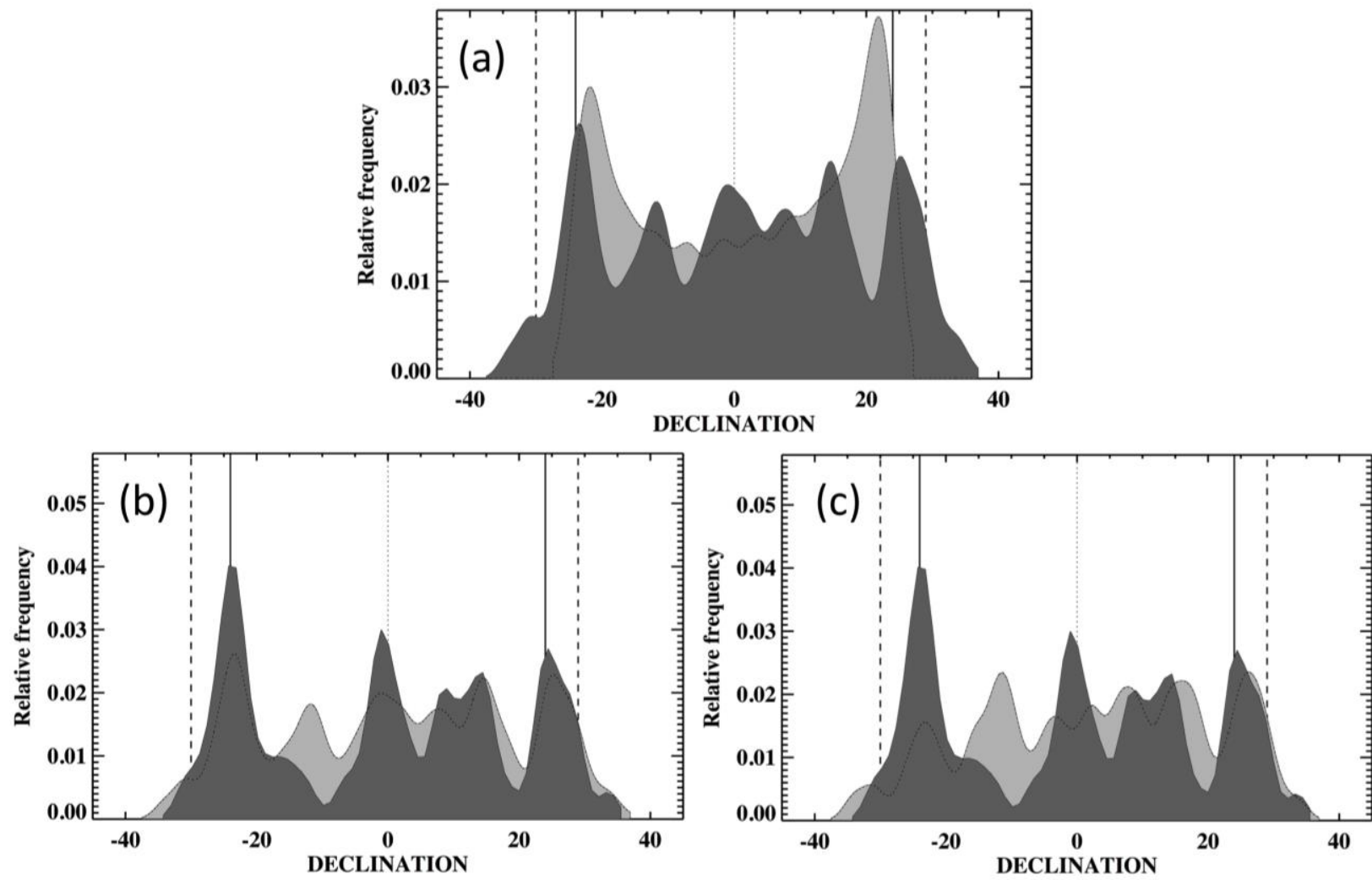

Fig. 6.3 (a) A declination histogram of the orientation of 181 Roman towns across the Roman west (dark grey) compared with the expected distribution of orientations in the course of a year if the orientations are supposed to follow the Sun on any day of the year (light grey). The solid vertical lines indicate the limits of the solar positions during the year (solstices), while the dashed vertical lines indicate the limits of the Moon. (b) Comparison of the declination histogram of the 64 Augustan towns measured in our sample and included in Table 1 (dark grey) with all the Roman towns measured so far by our group (light grey). (c) Comparison of the declination histogram of the 64 Augustan towns measured in our sample and included in Table 1 (dark grey) with the non-Augustan towns (light grey); vertical lines are as in Fig. 6.1 


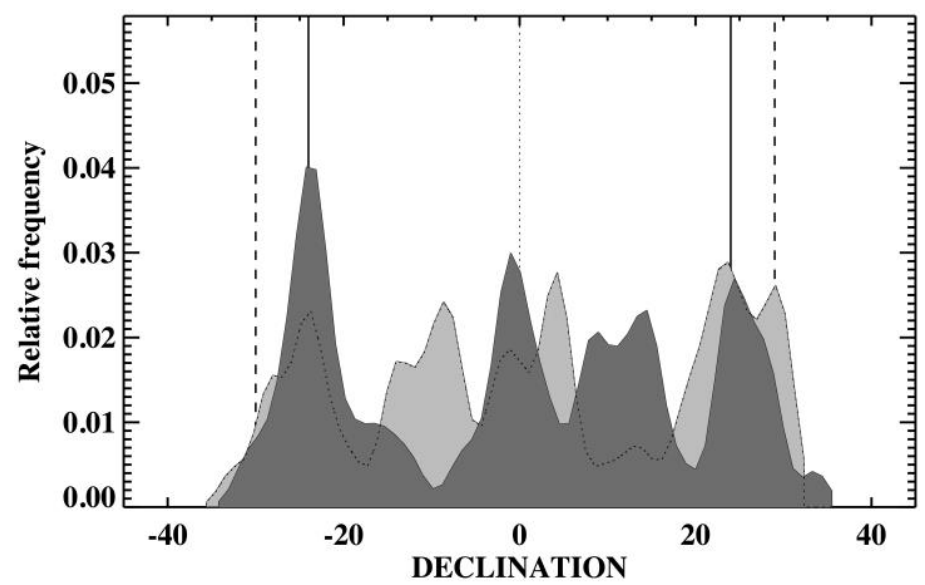

Fig. 6.4 Comparison between the eastern end of the decumani (dark grey) and the western part (light gray); vertical lines are as in Fig. 6.1

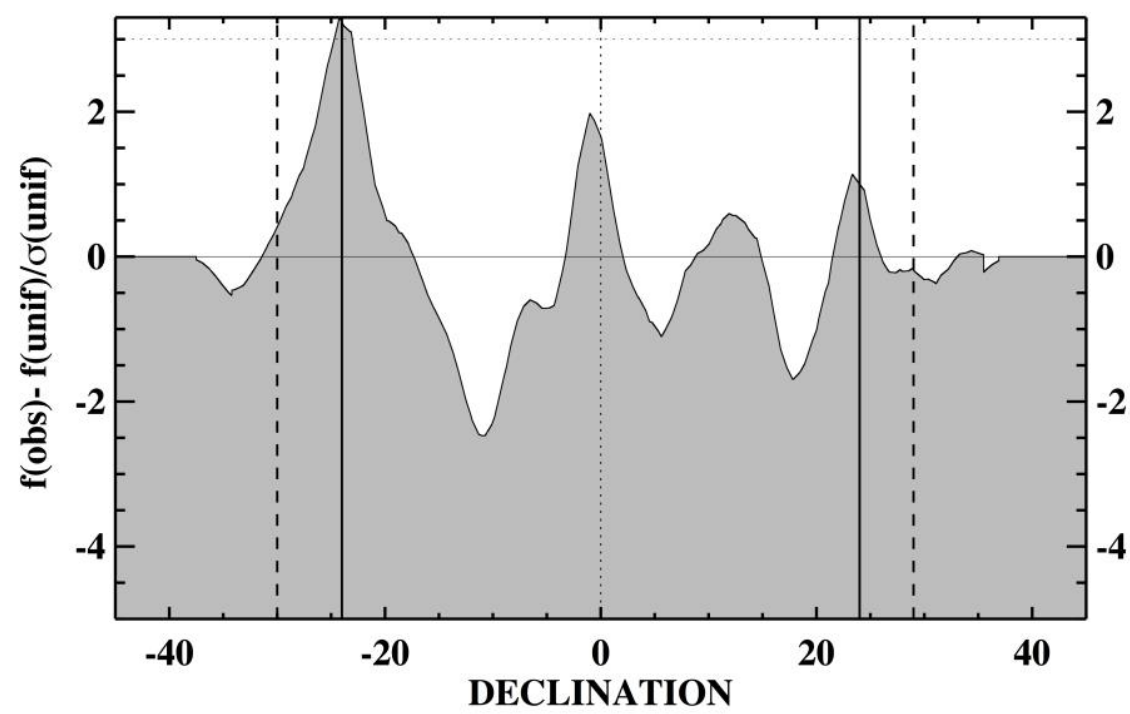

Fig. 6.5 Relative frequency of the Augustan towns ( $(\mathrm{obs})$ ) relative to the non-Augustan ones (f(unif)) in terms of the internal variation of the last ones; vertical lines as in Fig. 6.1; for details see the text

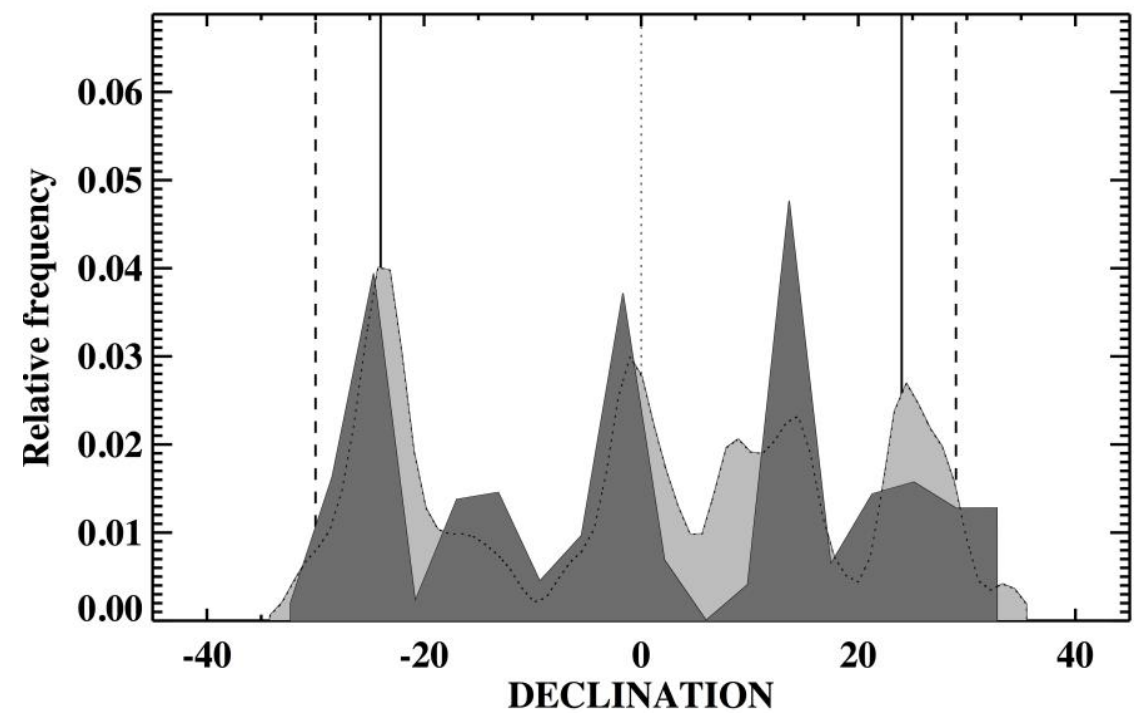

Fig. 6.6 A comparison of cities in our sample named 'Augusta' in dark grey with all Augustan towns (light grey); vertical lines as in Fig. 6.1 
Fig. 6.5 makes this comparison more explicit. It directly compares the prominence of the concentrations of the Augustan towns with those in the non-Augustan ones. In this sense, this diagram provides an indication of how significant these maxima are. In the natural sciences a value of 3 or above means a high relevance of the concentration, while in the humanities a value of 2 is more than acceptable. In this case, we have two clear maxima above the 2-sigma line: the Winter Solstice one and the equinoctial concentration. This clearly indicates that such directions, and possibly the dates associated with them in the Roman calendar, were of particular significance.

Finally, Fig. 6.6 includes only those towns in our sample that bear the name Augusta, to see if there is any difference with the rest of the Augustan settlements. We have only 18 such towns in our sample, and despite the low number statistics, we do not see any difference between this sample and the rest of towns for the three main maxima. The only major difference appears to be the concentration around declination $14^{\circ}$, which would correspond with the beginning of May or mid-August in a proleptic Gregorian calendar.

\subsection{Discussion and Conclusions}

Given the results expressed above regarding Figs. 6.1 to 6.6 we may conclude that Augustan towns were oriented following a definite pattern. Sunrise at a particular time of the year seems to have been important. For instance, Winter Solstice sunrise was a favorite choice in the orientation of Augustan towns. Other favoured times were the equinoxes and summer solstice. All of these were defined by a solar model that perhaps related Augustus to the Sun and, more specifically, to Apollo-Sol (Lange 2009; Rehak 2006).

In this respect, a mythical tale attributes Augustus' conception to the relationship between Apollo (transformed into a snake) and his mother Atia while she slept inside his temple in Campus Martius (Suet. Aug. 94, 4; the fatherhood of Augustus is also attributed to Apollo by Cassius Dio 45, 1, 2). According to Suetonius, while pregnant, Atia also dreamed that her innards were transported to the stars and scattered over the surface of the land and sea, and her husband Octavius dreamed that the glowing Sun emerged from Atia's womb (Suet. Aug. 94, 4; similarly, see Cass. Dio 45, 1, 3; Epigr. Bob. 39).

Augustus would not have hesitated to politically exploit his presumed divine filiation with Apollo from an early age. As reported by Suetonius, between 40 and $37 \mathrm{BCE}$, Octavian would have attended what was known as the 'dinner of the twelve gods' ( $\delta \omega \delta \varepsilon \kappa \alpha ́ \theta \varepsilon \circ \varsigma)$ dressed as Apollo (pro Apolline ornatum), although this presumptuous behavior was not well accepted by the populace (Suet. Aug. 70, 1-2; Kleiner 1988; Lange 2009; Del Hoyo 2011).

At about that time, Octavian would have promised to build a temple dedicated to Apollo during his campaign against Sextus Pompey (Suet. Aug. 29, 1; 29, 3; Mon. Anc. 19, 1; Plin. HN 36, 13; Vell. Pat. 2, 81, 3; Cass. Dio 49, 15, 5; Prop. 2, 31.). The construction work, which was not completed until 28 BCE, began immediately on land that he owned on the Palatine Hill alongside Augustus' house, which as stated in Suetonius had been chosen by Apollo with a lightning strike on that spot (Suet. Aug. 29, 3). According to the sources, a statue of Augustus stood within this area, in the guise of Apollo (Scholiast on Hor. Epist. 1, 3 17; Serv. Ecl. 4, 10; Kleiner 1988; Lange 2009; Rehak 2006).

Moreover, the House of Augustus had been honored through the planting of laurel trees (the sacred tree to Apollo) on both sides of the door, as well as placing the corona ciuica upon it (Mon. Anc. 34; Ov. Fast. 4, 951-954; Met. 1, 557-566). These laurel trees, in the opinion of Zanker (1988), would have given the entrance of the house a 'sacred aura'. According to Kleiner (1988: 350), “... whether Augustus wished to present himself as Apollo or simply as the god's son, he was following a venerable Eastern tradition in which a ruler was treated as a divinity." In fact, Augustus was honored in a number of Eastern towns, such as Athens, by dedicating sculptures to NeoApollo (allegedly dressed like this god) (Hoff 1992; Peppas-Delmousou 1979; Schmalz 2009). Furthermore, the dies natalis Augusti was celebrated in Athens with the typical offerings for Apollo during his feast day (SEG XVII, 34). Also, this connection is reflected in the sacerdotal organization in Athens at the beginning of the Principate where the priest of Rome and Augustus at the Acropolis (IG II2, 3173), Pamenes of Marathon, was also the priest of Delian Apollo (Inscr. Delos 1592; 1593; 1594; 1605; 1625; 2515; 2517 y 2518; for further discussion see Lozano Gómez 2007). Finally, a passage from Virgil (Aen. 8, 720-723) shows Augustus (after having been victorious in Actium) as ruler of the oecumene, enthroned at the blazing threshold of the Temple of Apollo, settling the matters of all countries and receiving dona. But the association between Augustus and the Sun is also documented for the West, since Horace (Carm. 4, 5, 5-8) describes Augustus' return to Rome after his stays in Hispania, Gallia and Germania between 16 and $13 \mathrm{BCE}$ as the Sun returning to the homeland.

This question, as it was proposed in a previous work (Espinosa-Espinosa and González-García 2017), is strongly tied to the orientation of Roman towns towards sunrise during the autumn equinox. If our interpretation is correct, the idea of linking the celebration of the dies natalis Augusti on 23 September with this astronomical event fits more closely with the idea of Augustus' association with Apollo-Sol and, therefore, with the alignment of Roman towns towards this date. This was something that Augustus himself may well have been seeking, after being proclaimed Pontifex Maximus, by decreeing the reformation of the calendar to bring it back in line with the seasons (González-García and Belmonte 2006). In fact, as has been supported by Bilić (2012), Apollo's relation with the annual solar movement in the ancient world seems clearly based on ancient Greek narrative, with an emphasis on the solstices. This identification appears to have continued in Roman times, as illustrated by Cicero (N.D. 3, 57) and 
Claudian (De VI Cons. Hon. 26-27). In fact, Herodian (5, 6, 6-8) describes a summer festival performed by Elagabalus in Rome, in which the Emperor ran backwards in front of a solar chariot driven by the deity. His running backwards, in the opinion of Bilić (2012), certainly symbolized the start of the Sun's backwards movement towards the south following the summer solstice.

A different case seems to be at stake with respect to the possibility of the fourth concentration related to the begining of May or mid August. There is no apparent Roman festival that can be clearly related with this concentration of orientations. Given the geographic location of the towns producing this concentration, this could be related to the culture previously existing in such areas. In this case, it is remarkable that a good number of those towns (5 out of 8) are from the Iberian Northwest where the classical writers indicate that the tribes had a Celtic cultural background, also attested by the theonims and toponims with Celtic roots found in these regions (GonzálezGarcía 2011; Luján Martínez 2009). Thus, in such areas there could have been a process of explicit or implicit negotiation between the need to impose the Romanness of the towns while including Celtic orientations, something similar to what has been mentioned earlier for Lugdunum, for the Gaulic tribes, or for Carthago Nova for the Punic population.

If we must suppose those towns to be the result of negotiations between the Romans trying to impose their model and the local elites trying to become Roman, it is interesting to see how such a model was implemented in different cases and how compromise was reflected in the orientation of towns. In certain areas this would imply a full acceptance of the Roman symbols, including in them the use of the Roman orientations, meaning those towards Winter Solstice and perhaps the Equinox, as directly related with Augustus. In other cases instead, such negotiation meant a mixture of a Roman town with local orientations. It seems remarkable in this sense that such cases do seem to point to the importance and resilience of Celtic elements. However, this last point could be the result of a certain selection effect, as our sample concentrates largely in areas where the Celtic population could have been important. It seems clear that in order to elucidate this issue we need further dedicated research in these areas, together with an investigation on what happened in other regions of the Roman Empire at the same time.

In addition, it would be interesting to see what happened before Augustus. Julius Caesar for instance founded a large number of towns as well. We could mention two that might seem indicative: Carthage and Corinth. Both cities, destroyed at $146 \mathrm{BC}$ were refounded as Roman colonies at the time of Caesar, and it is interesting to note that Carthago was oriented parallel to the coast line, but in such a way that is at the same time oriented towards Winter Solstice sunrise (Esteban 2003). Meanwhile, the Roman layout of Corith has a skewd orientation of $3^{\circ}$ with respect to the cardinal points (Gilman Romano 2003: 285). Such orientation, and taking into account the height of the horizon, indicates an orientation towards sunrise on 25 March, in the proleptic Gregorian Calendar. It is interesting that such a date was the traditional date for the equinox and was probably one of the dates that Julius Caesar considered when reforming the Republican Calendar to bring it in step with the seasons (González-García and Bemonte 2006).

It is highly indicative that both orientations appear as the most frequent ones in the latter Augustan foundings. In this sense it would also be advisable to extend this research in order to see if the settlements founded by Pompeius Magnus in the East do have a systematic orientation like those of later Roman rulers, to try and resolve whether the Hellenistic tradition came with him from the East.

\section{References}

Barton, T. (1995). Augustus and Capricorn: astrological polyvalency and imperial rhetoric. The Journal of Roman Studies, 85, 33-51.

Belmonte, J.A., \& González-García, A.C. (2010). Antiocho's Hierathesion at Nemrud Dag revisited: adjusting the date in the light of astronomical evidence. Journal for the History of Astronomy, 41, 469-482.

Belmonte, J.A., Noguera, J.M., González-García, A.C., \& Rodríguez-Antón, A. (2016). The materialization of sacred space: astronomy and landscape in Carthago Nova. In T. Lonsladen, \& F. Ventura (Eds.), The Materiality on the Sky, Proceedings of the SEAC 2014 Conference (pp. 65-78). Bath: Sophia Centre Press.

Bertarione, S.V., \& Magli, G. (2015). Augustus' power from the stars and the foundation of Augusta Praetoria Salassorum. Cambridge Archaeological Journal, 25(1), 1-15.

Bilić, T. (2012). Apollo, Helios, and the solstices in the Athenian, Delphian, and Delian calendars. Numen, 59, 509532.

Briquel, D. (2008). L'espace consacré chez les Étrusques: reflexions sur le rituel étrusco-romain de fondation des cites. In X. Dupré Raventós, S. Ribichini, \& S. Verger (Eds.), Saturnia Tellus. Definizioni dello Spazio Consacrato in Ambiente Etruco, Italico, Fenicio-Punico, Iberico e Céltico. (pp. 27-47). Rome: Consiglio Nazionale delle Ricerche.

Del Hoyo, J. (2011). Aprovechamiento político de los dioses por Augusto y su tiempo. In M. Campo (Ed.), Mites, Ofrenes Funeràries i Monedes. XV Curs d'Història Monetària d'Hispània. Barcelona, 24 i 25 de Novembre de 2011 (pp. 45-53). Barcelona: Museu Nacional d'Art de Catalunya.

Espinosa-Espinosa, D., \& González-García, A.C. (2017). A.D. VIIII Kalendas Octobres, Dies Natalis Augusti. Some considerations on the astronomical orientation of Roman Cologne and the imperial cult. Numen, 64, 1- 
23.

Esteban, C. (2003). Temples and astronomy in Carthage. In Calendars, Symbols, and Orientations: Legacies of Astronomy in Culture (pp. 135-142). Uppsala: Uppsala Astronomy (Observatory Reports, 59).

Ferro L., \& Magli, G. (2012). The astronomical orientation of the urban plan of Alexandria. Oxford Journal of Archaeology, 31, 381-389.

García Quintela, M.V., \& González-García, A.C. (2014). Le $1^{\text {er }}$ Août à Lugdunum sous l'Empire Romain: bilans et nouvelles perspectives. Revue Archáeologique de l'Est, 63, 157-177.

Gilman Romano, D. (2003). City planning, centuriation and land division in Roman Corinth: Colonia Laus Iulia Corinthiensis \& Colonia Iulia Falvia Augusta Corinthiensis. In Corinth 20, The Centenary: 1896-1996 (pp. 279-301). Athens: The American School of Classical Studies.

González, R., \& Ruiz de Arbulo, J. (Eds.), (2010). Simulacra Romae II. Rome, les Capitals de Province (Capita Provinciarum) et la Création d'un Espace Commun Européen. Une Aproche Archéologique. Reims: Societé Archéologique Champenoise.

González-Garcia A.C., \& Belmonte J.A. (2006). Which equinox? Archaeoastronomy, Journal for Astronomy in Culture, 20, 95-105.

González-García, A.C., \& García Quintela, M.V. (2014). The $1^{\text {st }}$ of August at Lugdunum: astronomy and Imperial cult in Galia. Mediterranean Archaeology and Archaeometry, 14(3), 83-91.

González-García, A.C., \& Magli, G. (2014). Roman city planning and spatial organization. In C.L.N. Ruggles (Ed.), Handbook of Archaeoastronomy and Ethnoastronomy (pp. 1643-1650). Heidelberg: Springer.

González-García, A.C., Rodríguez-Antón, A., \& Belmonte, J.A. (2014). The orientation of Roman towns in Hispania: preliminary results. Mediterranean Archaeology and Archaeometry, 14(3), 107-119.

González-García, A.C., et al. (2015). Orientatio ad Sidera: astronomía y Paisaje urbano en Qart Hadašt/Carthago Nova. Zephyrus, 75, 141-162.

González García, F.J. (2011). Los Célticos de Gallaecia: apuntes sobre etnicidad y territorialidad en la Edad del Hierro del Noroeste de la Península Ibérica. Complutum, 22(1), 117-132.

Gros, P., \& Torelli, M. (1994). Storia dell'Urbanistica. Il Mondo Romano. Roma: Editori Laterza.

Hannah, R., \& Magli, G. (2011). The role of the Sun in the Pantheon's design and meaning. Numen, 58, $486-513$.

Haselberger, L. (2014). The Horologium of Augustus: Debate and Context. Journal of Roman Archaeology, Supplementary Series, 99.

Hoff, M.C. (1992). Augustus, Apollo and Athens. Museum Helveticum, 49, 223-233.

Kaiser, A. (2011). Roman Urban Street Networks. New York: Routledge.

Kleiner, F.S. (1988). The Arch in honour of C. Octavius and the Fathers of Augustus. Historia, 37(3), $347-357$.

Lange, C.H. (2009). Res Publica Constituta. Actium, Apollo and the Accomplishment of the Triumviral Assignment. Leiden-Boston: Brill.

Laurence, R., Esmonde Cleary, S., \& Sears, G. (2011). The City in the Roman West c.250 BC-c.AD 250. Cambridge: Cambridge University Press.

Lozano Gómez, F. (2007). Los agones de los Augustos en Atenas. In M. Mayer, G. Baratta, \& A. Guzmán (Eds.), Provinciae Imperii Romani Inscriptionibus Descriptae (pp. 851-856). Barcelona: Institut d'Estudis Catalans.

Luján Martínez, E.R. (2009). Pueblos celtas y no celtas de la Galicia antigua. Fuentes literarias frente a fuentes epigráficas. In J. Aparicio Pérez, \& L. Silgo Gauche (Eds.), Real Acadèmia de Cultura Valenciana. Sección de Estudios Ibéricos D. Fletcher Valls. Estudios de Lenguas y Epigrafía Antiguas-ELEA $n^{\circ} 9$ (pp. 219-250). Valencia: Real Acadèmia de Cultura Valenciana.

Magli, G. (2008). On the orientation of Roman towns in Italy. Oxford Journal of Archaeology, 27(1), 63-71.

Owens, E.J. (1992). The City in the Greek and Roman World. New York: Routledge.

Pankenier, D.W. (2014). Astronomy and city planning in China. In C.L.N. Ruggles (Ed.), Handbook of Archaeoastronomy and Ethnoastronomy (pp. 1643-1650). Heidelberg: Springer.

Peppas-Delmousou, D. (1979). A statue base for Augustus IG II2 3262 + IG II2 4725. American Journal of Philology, 100, 125-132.

Rehak, P. (2006). Imperium and Cosmos. Augustus and the Northern Campus Martius. Madison: University of Wisconsin Press.

Rodríguez-Antón, A. (2017). Cosmovisión y Urbanismo en la Roma Antigua: Orientación de Ciudades y Campamentos Romanos. Ph.D. Thesis, Universidad de La Laguna, Spain.

Rodríguez-Antón, A., González-García, A.C., \& Belmonte, J.A. (2017). Estimating the reliability of digital data acquisition in Cultural Astronomy. Its use in the case of Roman North Africa. Journal of Skyscape Archaeology, 3 (2), 191-206.

Rykwert, J. (1988). The Idea of a Town. The Anthropology of Urban Form in Rome, Italy and the Ancient World. Princeton: Princeton University Press.

Schmalz, G.C.R. (2009). Augustan and Julio-Claudian Athens. A New Epigraphy and Prosopography. LeidenBoston: Brill.

Woodward, P., \& Woodward, A. (2004). Dedicating the town: urban foundation deposits in Roman Britain. World Archaeology, 36(1), 68-86. 